\title{
DO PRINCÍPIO DA LEGALIDADE AO DA JURIDICIDA- DE ADMINISTRATIVA: A APRECIAÇÃO DE CONSTI- TUCIONALIDADE PELA ADMINISTRAÇÃO PÚBLICA
}

\author{
From the principle of legality to administrative lawfulness: the \\ constitutionality assessment by Public Administration
}

\section{Romano Scapin}

Mestre em Direito pela Universidade Federal do Rio Grande do Sul (UFRGS). Auditor Público Externo do Tribunal de Contas do Estado do Rio Grande do Sul.

\section{Resumo}

O artigo apresenta reflexões sobre as consequências teóricas e práticas para Administração Pública advindas da evolução de paradigma principiológico administrativo, cujo ponto de origem parte do princípio da legalidade (em sentido estrito) e o de chegada encontra a concepção e entendimento quanto ao princípio da juridicidade - também denominado de princípio da legalidade em sentido amplo. Os efeitos causados à Administração pela modernização conceitual do princípio da legalidade autorizam e exigem dela o poder-dever de apreciação da constitucionalidade de normas infraconstitucionais, observando determinados procedimentos que formalizem a atuação administrativa e, sempre, respeitem todos os demais princípios constitucionais, em especial os do contraditório e ampla defesa naquelas situações em que direitos/interesses de particulares possam ser atingidos.

Palavras-chave: Direito Administrativo. Administração Pública. Princípio da legalidade. Princípio da juridicidade. Apreciação de constitucionalidade.

\begin{abstract}
The article presents reflections about the theoretical and practical consequences for the Public Administration arising of the evolution of administrative principle paradigm, whose point of origin parts from the principle of lawfulness (in the strict sense) and whose arriving point finds the conception and understanding of the principle of legality - also denominated of principle of lawfulness in an ample sense. The effects caused to the Administration by the conceptual modernization of the principle of legality authorize it and demand from it the power-duty to assess the constitutionality of infraconstitutional nor$\mathrm{ms}$, observing certais procedures that formalize the administrative actions and, always, respect all the others constitutional principles, specially those of contradictory and broad defense in those situations in which the rights / interests of individuals may be attained.
\end{abstract}

Keywords: Administrative law. Public administration. Principle of legality. Consideration of constitutionality

\section{Sumário}

1. Introdução; 2. Princípio da Legalidade; 2.1 Contexto histórico da origem do princípio; 2.2 Primazia da Lei e Reserva Legal; 3. Princípio da Juridicidade; 3.1 Contexto e circunstâncias da mudança de paradigma para a juridicidade; 3.2 Princípio da juridicidade e atuação administrativa; 4. Problematização do Princípio da Juridicidade; 4.1. Apreciação de constitucionalidade de leis no âmbito do Poder Executivo; 4.2. Apreciação de constitucionalidade pela Administração Pública: aspectos de imprescindível observância nos procedimentos correlacionados; 5 . Conclusões; 6 . Notas; Referências 


\section{INTRODUÇÃO}

O presente trabalho abordará relevante aspecto da relação do princípio da legalidade em sentido amplo, também denominado de princípio da juridicidade, e a atuação da Administração Pública. ${ }^{1}$ Mais especificamente, o escopo do trabalho cingir-se-á ao exame da possibilidade de apreciação de constitucionalidade dos instrumentos normativos infraconstitucionais realizada pela Administração Pública, no Estado brasileiro.

Pretende-se, na primeira parte do trabalho, examinar a evolução do princípio da legalidade, desde sua origem até os dias de hoje, relacionando-o, principalmente, à Administração Pública brasileira.

Chegando à definição contemporânea do princípio analisado, buscar-se-á a avaliação dos reflexos causados à Administração pela modernização conceitual do núcleo jurídico do princípio da legalidade.

Na sequência, a pesquisa recairá sobre a análise doutrinária a respeito da possibilidade de apreciação da constitucionalidade de normas infraconstitucionais por parte da Administração Pública.

$\mathrm{Na}$ etapa seguinte e conclusiva, buscar-se-á relacionar a primeira parte com a segunda, isto é, a correlação entre a visão contemporânea do princípio da legalidade e a possibilidade de apreciação de constitucionalidade da legislação infraconstitucional por parte da Administração Pública.

\section{PRINCÍPIO DA LEGALIDADE}

\subsection{CONTEXTO HISTÓRICO DA ORIGEM DO PRINCÍPIO}

A opção da humanidade em organizar-se por meio do Direito escrito decorreu da evolução da vida em sociedade e da respectiva conclusão de que é necessário registrar expressamente os regramentos de conduta. Tal opção facilitaria a manutenção e o desenvolvimento da sociedade e o convívio de seus membros e foi, por assim dizer, "escolhida" pela civilização ocidental há milhares de anos. ${ }^{2}$

As regras escritas, portanto, para regulamentar a relação entre civis (particulares) foram adotadas desde muito cedo pelos homens que desejavam organizar-se em sociedade.

De outro lado, é muito mais recente a percepção de que também para as relações que envolvessem o Estado personificado e seus cidadãos havia necessidade de adoção do Direito escrito. Nessa segunda situação, a necessidade vislumbrada objetivava excluir o arbítrio do Poder Público, ensejando que as atividades estatais fossem, de certa forma, regradas, previsíveis e limitadas. A ideia podia ser resumida com a seguinte assertiva lógica: onde existe lei, não pode haver arbítrio. ${ }^{3}$

Dessa forma, pode-se afirmar que a noção de legalidade foi construída a partir da própria evolução da humanidade. Quanto a um marco histórico de início da prática da legalidade na relação do Estado com os particulares, costuma-se atribui-lo à Magna Carta inglesa, de 1215, a qual exigia, entre outras situações, a autorização dos representantes dos contribuintes para legitimar qualquer cobrança de tributos, a necessidade de previsão 
legal para definir condutas que levassem à prisão, à perda da propriedade, ou tornassem o cidadão fora da lei.

Alguns séculos depois, outro marco importante histórico na consolidação da legalidade que merece registro é a elaboração da Petition of Rights, em 1628, na Inglaterra, oriunda da disputa de poder entre o Rei e o Parlamento, que estabeleceu liberdades civis a serem respeitadas pelo Monarca. Por meio desse instrumento, foram previstas ao Rei da Inglaterra, Carlos I, obrigações no sentido de respeitar os direitos dos cidadãos. Ademais, merece registro também que, poucas décadas depois, em 1689, foi aprovado, mais uma vez na Inglaterra, o Bill of Rights, que era uma relação de direitos e garantias conferidas ao indivíduo contra o poder estatal.

Os fatos históricos ingleses geraram tentativas teóricas e práticas no sentido de definir, diferenciar e separar as formas de atuação do poder estatal. De fato, a mais importante foi a que resultou na caracterização da lei como norma permanente, obrigatória para todos, inclusive para o próprio Estado-legislador e, portanto, geral, que não pode dirigir-se a um caso particular. Tais características naturalmente distinguiram a lei dos demais instrumentos de consecução da atividade estatal.

Entre os séculos XVI e XVIII, período reconhecidamente marcado como época da afirmação do racionalismo filosófico, ${ }^{4}$ desenvolveram-se as teses do contratualismo social, ${ }^{5}$ aprofundando-se, principalmente na França, o desenvolvimento pela doutrina do princípio da legalidade.

Com efeito, o princípio da legalidade que foi, por assim dizer, importado ao Brasil é de origem francesa, razão pela qual cabe explanação mais detalhada sobre o contexto histórico francês da época embrionária do princípio aqui tratado.

A Revolução Francesa de 1789 representou a passagem da Idade Média para a Idade Moderna, como evento histórico simbólico, justamente por marcar o início de uma nova era na sociedade civilizada ocidental: o advento da burguesia ao poder político e o surgimento de um Estado de Direito como forma de organização personificada do Poder Público, no qual o princípio da legalidade passou a ser um dos alicerces no novo regime.

Aquele momento histórico da Revolução representava uma superação do Antigo Regime, do modelo absolutista de governar, liderado pela burguesia e seus ideais liberais e iluministas.

John Locke e Montesquieu, filósofos símbolos do lluminismo, foram pensadores que influenciaram a Revolução Francesa. Locke entendia que a lei seria o grande instrumento e meio para se alcançar a formação da sociedade e o desfrute da propriedade em paz e segurança. O pensador Rousseau corroborou as ideias dos demais filósofos trazendo a relação de vontade geral vinculada à concepção de lei.

Tais ideias e visão de Estado guardavam relação, logicamente, com a forma de compreender o Direito. A Ciência Jurídica deveria, na visão iluminista, expressar-se precisamente por meio de leis, as quais gerariam normas jurídicas que seriam válidas não por necessariamente serem justas, mas por terem sido postas por uma autoridade dotada de 
competência normativa.

O período do lluminismo assentou-se na ideia de que deveria ser possível estabelecer uma clareza e uma segurança jurídica absolutas por meio de normas rigorosamente elaboradas e, especialmente, garantir uma univocidade incondicional a todas as decisões judiciais. Nessa visão iluminista, aliás, fundamenta-se o positivismo jurídico.

Na França do final do século XVIII, a lei, insuspeita em qualquer situação já que era expressão da vontade geral, representava uma atuação do Estado no sentido de oferecer uma moldura puramente formal, dentro da qual a sociedade vivia seu próprio dinamismo espontâneo. Em decorrência lógica dessa premissa, tinha-se a proeminência absoluta do Poder Legislativo sobre os demais Poderes.

Por oportuno, cabe salientar que, na Declaração de Direitos do Homem e do Cidadão (1789), em seus arts. $5^{\circ}$ e $6^{\circ}$, havia previsão de que tudo que não está proibido pela lei não pode ser impedido e ninguém pode ser obrigado a fazer o que ela não ordena. Por outro lado, cumpre destacar que o princípio da legalidade no molde constitucional francês da época da Revolução (tanto nas Constituição de 1791, quanto nas duas seguintes - de 1793 e 1795) tinha um viés positivo para a Administração Pública, de forma que esta somente podia fazer aquilo que constava na lei.

Nesse sentido, destaca-se a distinção de características entre o Direito Privado, no qual a lei exerce um papel negativo, e o Direito Público, especialmente o Direito Administrativo, no qual a lei cumpre um papel positivo, já que ela representa o instrumento que, no Estado Democrático de Direito, fundamenta a atuação da Administração Pública. Assim, a lei para a Administração Pública não será somente o limite de atuação, mas também a sua fonte.

Destarte, nos parágrafos acima, resumiu-se o contexto histórico da origem do princípio da legalidade, importando passar, nesse ponto, a discorrer sobre as duas facetas que conformam o princípio examinado: a primazia da lei e a reserva legal.

\subsection{PRIMAZIA DA LEI E RESERVA LEGAL}

O princípio da legalidade é composto por duas facetas, ou, dizendo de outro modo, por dois subprincípios, que, muito antes de serem componentes estanques e intangíveis entre si, estão em conexão um com outro: a primazia (ou supremacia) da lei e a reserva legal.

O primeiro dos subprincípios citados, o da primazia ou supremacia da lei, significava, à época do surgimento da concepção de legalidade, que a lei devia estar posta como vetor máximo, dentro de um ordenamento jurídico, para validação da atuação administrativa. Em sua origem, o princípio da legalidade, por meio do conceito construído para explicar a faceta da primazia da lei, compreendia a ideia de que a lei era o princípio basilar do Estado de Direito, sendo a expressão jurídica da hegemonia da burguesia liberal no Poder. Em consequência, a lei era reconhecida com superioridade de validação da atuação administrativa frente a todos os demais atos jurídicos, inclusive frente ao próprio documento constitucional - até porque este continha muito mais disposições acerca da estrutura política do Estado do que normas jurídicas para atuação do Poder Público. Atualmente, o significado da primazia 
da lei foi ampliado, de modo que a Constituição tomou seu posto como vértice normativo superior para validação da atuação da Administração Pública, conforme será mais adiante visto pormenorizadamente.

Quanto ao sentido jurídico da primazia da lei, o professor Itiberê de Oliveira Rodrigues ensina que: ${ }^{6}$

\begin{abstract}
Em relação a todas as atividades da Administração Pública, esse princípio significa que ela necessita observar e aplicar as leis e que ela não pode substituir os comandos legais por suas próprias decisões. Isso significa, por conseguinte, que em virtude dessa primazia ou supremacia da lei a Administração Pública somente pode agir secundum legem ou praeter legem, nunca, porém, contra legem. Assim agindo, seus atos serão inválidos.
\end{abstract}

De outro lado, o subprincípio da reserva legal diz respeito a atuação administrativa estar embasada e limitada aos preceitos previstos em lei.

No ponto, cabe comentar a evolução da doutrina alemã a respeito desse subprincípio. Conforme citado pelo jurista Otto Mayer, a vinculação administrativa à lei, num primeiro momento, era considerada negativa (negative Bindung), em razão de que a legalidade representaria uma limitação para a atuação do administrador, de modo que, na ausência da lei, poderia este atuar com maior liberdade para atender o interesse público. A predominância da ideia de vinculação negativa perdurou, aproximadamente, até a primeira guerra mundial, a partir de quando, por influência dos estudos de Kelsen, a vinculação da Administração à lei passou a ser classificada como positiva, isto é, o Administrador apenas poderia agir exatamente de acordo com os preceitos legais. Em outras palavras: a ausência de lei obstaria à atuação do administrador público

De fato, o entendimento sobre reserva legal mais difundido no Brasil foi o segundo, no sentido de que, apenas com autorização legal expressa, seria válida a atividade da Administração Pública, ou seja, a Administração Pública não poderia agir senão legitimada por preceitos legais.

Atualmente, o estudo do subprincípio "responde à questão se e até que ponto é necessária uma autorização legal expressa para que a Administração Pública possa agir frente a um determinado âmbito ou fato da vida concreta."

Isto é, não é toda atuação administrativa que depende, para sua validação, de prévia lei autorizativa, o que significa dizer, conforme vozes doutrinárias que serão reproduzidas posteriormente, que os mandamentos ordenados pela Constituição, diante da evolução do princípio da legalidade, já seriam suficientes, autorizadores e, ainda, impositivos para que o Administrador atue para sua concretização, especialmente quando forem referentes a direitos individuais.

Quanto à classificação da reserva legal, a doutrina não é uníssona ao escolher as denominações catalogadas. O administrativista Itiberê, por exemplo, dividiu-a em três diferentes espécies: a reserva legal geral, a reserva legal especial ou específica e a reserva legal total. A primeira refere-se à proteção dos direitos de liberdade e propriedade das pessoas contra atos ablativos ou ablatórios da Administração Pública e está consagrado no nosso Direito, no art. $5^{\circ}$, inciso II, da Constituição da República: "ninguém será obrigado a fazer ou 
deixar de fazer alguma coisa senão em virtude de lei". A segunda espécie diz respeito aos casos em que a norma constitucional exige uma lei para a regulação de determinada matéria, sendo exemplo as disposições da Carta Magna brasileira inseridas nos artigos $33^{8}$ e $88 .^{9}$ Por fim, a terceira modalidade de reserva legal é aquela "que pode ser deduzida basicamente via interpretação sistemática dos dispositivos reguladores da repartição de competências normativas entre o Poder Legislativo e o Poder Executivo: se a este não se reconhece constitucionalmente nenhuma competência normativa originária ou exclusiva (ou impossibilidade de atividade praeter legem), então caberá somente ao Poder Legislativo a competência para inovar a ordem jurídica."10 Concluindo seu raciocínio, o jurista gaúcho afirma que, nesses casos, "a atividade administrativista fica com isso totalmente dependente de prévia lei autorizadora, sem o que será inválida."11

Não obstante, esta conclusão do professor Itiberê quanto à "reserva legal total" não se aplica integralmente no sistema constitucional brasileiro. ${ }^{12}$

Cabe mencionar, no ponto, ensinamento de Odete Medauar que, citando a doutrina de Charles Eisenmann, aponta quatro concepções do princípio da legalidade, na sua faceta de reserva legal, cujos critérios definidores são a intensidade de vinculação da Administração à norma legal:

Tornaram-se clássicos os quatro significados arrolados pelo francês Eisenmann: a) a Administração pode realizar todos os atos e medidas que não sejam contrários à lei; b) a Administração só pode editar atos ou medidas que uma norma autoriza; c) somente são permitidos atos cujo conteúdo seja conforme um esquema abstrato fixado por norma legislativa; d) a Administração só pode realizar atos ou medidas que a lei ordena fazer. ${ }^{13}$

$\mathrm{Na}$ classificação acima apresentada, a jurista vai afastar a possibilidade de aplicação da terceira e quarta concepções, na medida em que acarretariam, respectivamente, a ideia de Administração como mera "executora da lei" e a paralisação da Administração, "porque seria necessário um comando legal específico para cada ato ou medida editados pela Administração".

De fato, a segunda concepção da classificação apresentada é a que predominou no Direito brasileiro por muitos anos - e ainda é adotada em muitos manuais de Direito Administrativo. Na famosa lição de Hely Lopes Meirelles, apoiado em Guido Zanobini, compreendia-se a legalidade no que tange à reserva legal: "Enquanto na administração particular é lícito fazer tudo que a lei não proíbe, na Administração Pública só é permitido fazer o que a lei autoriza." 14

Todavia, conforme ressalta Odete Medauar, esta ideia - ainda muito presente na doutrina pátria - merece aplicação criteriosa, pois, em certos casos, "a norma legal apenas estabelece a competência para a adoção de certas medidas ('norma de competência'), deixando ampla margem de liberdade para o agente fixar o conteúdo da medida." ${ }^{15}$

Cabe registrar, ainda, que, além da segunda acepção (legalidade como "habilitação legal"), se pode considerar que o ordenamento jurídico pátrio aceita também a primeira visão de legalidade acima transcrita, segundo a qual é vedado à Administração editar atos ou tomar medidas contrárias às normas legais do ordenamento. 
Nada obstante, pretende-se avaliar, a partir do próximo capítulo, se a ampliação do sentido do princípio da legalidade, mutação já referida alhures, trouxe reflexos - e, caso positivo, em quais medidas - às concepções citadas que definem os subprincípios que compõem a legalidade administrativa: o da supremacia da lei e da reserva legal.

\section{PRINCÍPIO DA JURIDICIDADE ADMINISTRATIVA}

\subsection{CONTEXTO E CIRCUNSTÂNCIAS DA MUDANÇA DE PARADIGMA PARA A JURIDICIDADE ADMINISTRATIVA}

O princípio da juridicidade é considerado pela doutrina como uma mudança de paradigma em relação ao princípio da legalidade. A alteração paradigmática é simples de entender: se antes dizia-se que a atuação administrativa estava vinculada à lei, passou-se, a partir do reconhecimento da juridicidade administrativa, ao reconhecimento de que a atuação da Administração Pública está vinculada não só a lei, mas também ao Direito.

No presente tópico, pretende-se explorar mais detalhadamente o contexto e as circunstâncias da mudança de paradigma referida.

Com efeito, na hipótese de se resumir os principais motivos de tal mudança, é correto afirmar que a transição da legalidade para juridicidade começou pelo desprestígio do legislador e a crise da lei formal como fenômenos universais. Explicando mais detalhadamente o contexto que desencadeou tal situação, o jurista Gustavo Binenbojm elencou cinco fatores importantes.

O primeiro foi a proliferação ou inflação legislativa: o excesso de leis em todas as nações civilizadas, notadamente nos países de tradição romano-germânica, foi uma situação que acabou, naturalmente, desprestigiando a norma do parlamento.

O segundo elemento: a constatação histórica de que a lei pode, muito além de veicular a injustiça, ser fundamento para a barbárie. Lembrando que, em sua origem, a concepção de legalidade preconizava que toda a lei é válida independentemente de seu conteúdo, desde que reúna a um só tempo a generalidade da vontade e do seu próprio objeto. Em outras palavras, é dizer que a lei, em sua concepção inata, não se preocupava com a justiça.

O terceiro fator, talvez o mais importante, é que a lei deixou de ser a principal e mais importante forma de manifestação geral do povo. Diante do fracasso da lei nesse sentido, notadamente no segundo pós-guerra, as esperanças de garantia da liberdade e da justiça passam a ser depositadas no constitucionalismo. A maior prova disso foi a criação dos tribunais e órgãos constitucionais mundo afora, inclusive na França, berço da legalidade administrativa.

O quarto diz respeito com a criação de uma série de atos normativos infraconstitucionais, além da lei, capazes de servirem de fundamento da atuação administrativa - como, por exemplo, Medidas Provisórias, Leis delegadas e regulamentos autônomos - art. 84, VI, "a", da CF (após redação da EC 32/2001).

O quinto e último elemento citado pelo professor Binenbojm fundamenta-se no fato de que, mesmo não tendo o Executivo a atribuição normativa de que necessita para embasar 
sua atuação, não resta ao Legislativo muito espaço de atuação independente. Isso ocorre tendo em vista, como principais fatores, as inúmeras reservas de iniciativa legal ao Executivo (o que deixa o Legislativo condicionado à atuação prévia do Executivo) e o trancamento de pauta proposital causado pelas sólidas bases parlamentares típicas de um presidencialismo de coalizão.

Sem dúvida, diante do fracasso da lei em razão do não atingimento dos fins para os quais foi pensada e concebida, as ideias constitucionalistas surgiram como solução para contornar os problemas até então insolúveis para a legalidade. A Constituição de uma nação ganhou destaque máximo dentro de um ordenamento jurídico, o qual apenas poderia ser compreendido a partir da compreensão do próprio sistema normativo constitucional. Nesse contexto, passou-se a falar numa "constitucionalização do direito."16

Os reflexos de tal fenômeno, o da constitucionalização do direito, recaíram sobre praticamente todos os ramos das Ciências Jurídicas, tendo trazido, no Direito Administrativo, mudança de paradigma quanto à legalidade administrativa, em suas duas facetas (o da reserva legal e o da supremacia da lei). Nessa linha de raciocínio, é imperioso transcrever lição de BINENBOJM ${ }^{17}$ a respeito da substituição da lei pela Constituição dentro de um ordenamento jurídico:

\begin{abstract}
A superioridade formal e a ascendência axiológica da Constituição sobre todo o ordenamento jurídico produzem uma importantíssima modificação no direito administrativo: a lei é substituída pela Constituição como a principal fonte desta disciplina jurídica. ${ }^{18} \mathrm{~A}$ reserva vertical de lei foi substituída por uma reserva vertical de Constituição. ${ }^{19} \mathrm{~A}$ Constituição passa a figurar como norma diretamente habilitadora da atuação administrativa, havendo uma verdadeira osmose entre a 'Constituição e a lei.' ${ }^{20}$ Pode-se, assim, dizer, com Canotilho, que se abre caminho para 'uma legalidade sem lei'. ${ }^{21}$

Com efeito, a Constituição se presta (i) não só como norma direta e imediatamente habilitadora de competências administrativas, como também (ii) serve de critério imediato da tomada de decisão administrativa. ${ }^{22} \mathrm{~A}$ Constituição, porém, não só é fonte direta de habilitação de competências administrativas, funcionando também como critério imediato da tomada de decisões pelo administrador. Neste aspecto, evidencia-se a constitucionalização do Direito Administrativo, numa clara limitação dos espaços discricionários da Administração Pública, que se devem pautar não apenas pela finalidade legal, como também pelos fins constitucionais.
\end{abstract}

Portanto, resta claro que a expressão de outrora "supremacia da lei", agora, deve ser lida como "supremacia da Constituição" - ainda que a lei continue, em relação aos demais instrumentos infraconstitucionais, tendo preferência ${ }^{23}$-, bem como que o núcleo jurídico da "reserva de lei" não tem o mesmo sentido de anteriormente tendo em vista a possibilidade, defendida por parte da doutrina, de existir atuação administrativa mesmo sem lei, apenas com base na Constituição.

Assim, conclui-se que o contexto definidor da mudança de paradigma da legalidade à juridicidade foi, principalmente, o fenômeno da constitucionalização do direito, que refletiu profundamente nos estudos do Direito Administrativo e, consequentemente, na análise dos aspectos essenciais da atuação administrativa. 


\subsection{PRINCÍPIO DA JURIDICIDADE E ATUAÇÃO ADMINISTRATIVA NO SISTEMA JURÍDICO BRASILEIRO}

O princípio da juridicidade determina, como já dito, que a vinculação da atuação administrativa deve estar relacionada não apenas às leis, como determinava a legalidade ${ }^{24}$ mas a todo o ordenamento jurídico sistêmico, isto é, deve observar a um denominado "bloco de legalidade"25 composto pela Constituição, com seus princípios e regras, as leis, os regulamentos gerais e setoriais. ${ }^{26}$

Cabe mencionar que a juridicidade administrativa foi consagrada, expressamente e em nível constitucional, por três importantes ordenamentos jurídicos europeus. Na Alemanha, o art. 20, §3º da Lei Fundamental de Bonn (1949) prevê a vinculação do Poder Executivo e dos Tribunais à lei e ao direito. Na mesma linha, as Constituições espanhola (1978) e portuguesa (1976), ambas por influência do constitucionalismo germânico, previram, respectivamente, que "a Administração Pública serve com objetividade aos interesses gerais e atua de acordo com os princípios da eficácia, hierarquia, descentralização, desconcentração e coordenação, com submissão plena à lei e ao direito." ${ }^{27}$ (art. 103, 1); e que "os órgãos e agentes administrativos estão subordinados à Constituição e à lei e devem atuar com justiça e imparcialidade no exercício de suas funções"28 (art. 266, 2).

Não obstante os exemplos citados, a Constituição brasileira, de 1988, não foi tão clara e expressa ao tratar da vinculação normativa da Administração Pública ao Direito. Como é consabido, o art. 37, caput, da Carta Magna brasileira apenas prevê que "a administração pública direta e indireta de qualquer dos Poderes da União, dos Estados, do Distrito Federal e dos Municípios obedecerá aos princípios de legalidade, impessoalidade, moralidade, publicidade e eficiência e, também, ao seguinte: [...]". Todavia, a Lei n. 9.784/99, que regulamenta o processo administrativo federal, prevê em seu art. $2^{\circ}$, parágrafo único, inciso I, tendo sido igualmente influenciada pelo direito germânico, que:

\footnotetext{
Art. $2^{\circ}$ - A Administração Pública obedecerá, dentre outros, aos princípios da legalidade, finalidade, motivação, razoabilidade, proporcionalidade, moralidade, ampla defesa, contraditório, segurança jurídica, interesse público e eficiência.

Parágrafo único. Nos processos administrativos serão observados, entre outros, os critérios de:

I - atuação conforme a lei e o Direito;
}

Desse modo, pode-se dizer que até o legalista em sentido estrito mais convicto, que não reconhecesse a mudança de paradigma da legalidade à juridicidade, teria dificuldades em defender sua convicção em razão de constar como regra expressa na lei a obrigação de a Administração Pública observar a lei e o Direito.

De qualquer sorte, ainda que assim não fosse e não houvesse previsão legal da submissão da Administração ao Direito, a interpretação sistêmica da constituição impõe a conclusão pela adoção da juridicidade administrativa. Esse é o entendimento da melhor doutrina administrativista nacional, a qual se traduz no seguinte trecho da renomada professora Di Pietro: 


\begin{abstract}
No Brasil, embora não se repita norma com o mesmo conteúdo [do art. 20, §3 da Lei Fundamental de Bonn], não há dúvida de que se adotou igual concepção, já a partir do preâmbulo da Constituição, rico na menção a valores como segurança, bem estar, desenvolvimento, igualdade e justiça. Além disso, os artigos $1^{\circ}$ a $4^{\circ} \mathrm{e}$ outros dispositivos esparsos contemplam inúmeros princípios e valores, como os da dignidade da pessoa humana, o da moralidade, publicidade, impessoalidade, economicidade, dentre outros. Todos esses princípios e valores são dirigidos aos três Poderes do Estado: a lei que os contrarie será inconstitucional; a discricionariedade administrativa está limitada pelos mesmos, o que significa a ampliação do controle judicial, que deverá abranger a validade dos atos administrativos não só diante da lei, mas também perante o Direito, no sentido assinalado. (grifou-se).
\end{abstract}

De fato, pode-se afirmar com tranquilidade que o princípio da juridicidade administrativa está devidamente reconhecido e inserido no ordenamento jurídico pátrio, uma vez que, além de contar com vozes praticamente uníssonas na doutrina prestigiando-o, é citado com naturalidade (e certa frequência) pela jurisprudência da maior Corte de Justiça Nacional (o Supremo Tribunal Federal), conforme se exemplifica com o precedente a seguir:

Com o advento da Constituição da República de 1988 foi ampliado o conceito da
legalidade, sob o prisma axiológico. Dentro desse conceito amplo de legalidade,
a atividade administrativa deve estar pautada nos princípios gerais de direito
e nos princípios constitucionais, sob pena de ser considerada ilegal, por não
atender aos fins públicos colimados no Estado Democrático de Direto. (RMS n
16.536-PE, 02-02-2010).

Portanto, é certo que o princípio da juridicidade administrativa substituiu o princípio da legalidade administrativa nos sistemas jurídicos onde este era o balizador da atuação da Administração Pública, inclusive no sistema brasileiro.

Firmado esse ponto, pretende-se apontar duas consequências, por assim dizer, práticas à atuação administrativa ante a consagração do princípio da juridicidade: (a) a maior limitação da discricionariedade administrativa, na medida em que o agente administrativo deverá justificar sua escolha tendo em vista não apenas os termos legais, mas também os preceitos constitucionais, do que se tem, consequentemente, que o controle à Administração passa a ser ampliado; (b) os eventuais conflitos entre a aplicação da juridicidade e da legalidade em sentido estrito simultaneamente, uma vez que a legalidade administrativa perde seu posto para a juridicidade administrativa, mas não desaparece completamente, porquanto aquela (aí denominada de "legalidade em sentido estrito") passa a ser englobada por esta ("legalidade em sentido amplo"), como um de seus princípios internos.

O primeiro efeito já foi tratado tangencialmente acima e, por não ser objeto principal da presente pesquisa, não será aprofundado. No entanto, a segunda consequência prática (a relação da juridicidade com a legalidade) é de extrema relevância para este trabalho, na medida em que a atuação administrativa, a partir da juridicidade e tendo como referência a Lei, poderá seguir três situações distintas: 1) a atuação administrativa deverá ser segundo a lei (secundum legem), quando esta for constitucional; 2) mas, também, poderá ser diretamente vinculada à Constituição, independente ou para além da Lei (atividade praeter legem); 3) ou, eventualmente, poderá legitimar-se perante o Direito, ainda que contra a lei (contra legem). ${ }^{29}$

Ao presente trabalho, interessa aprofundar a análise da terceira situação apontada, os casos em que a atuação administrativa pode ocorrer contra legem, o que será problema- 
tizado no próximo item.

\section{PROBLEMATIZAÇÃO DO PRINCÍPIO DA JURIDICIDADE}

\subsection{APRECIAÇÃO DE CONSTITUCIONALIDADE DE LEIS NO ÂMBITO DO PODER EXECUTIVO}

Diante do que foi discorrido até o presente ponto, pode-se concluir, com a tranquilidade de não correr risco do equívoco, que a legalidade administrativa, em seu sentido estrito, facilitava o exercício da função administrativa: ${ }^{30}$ bastava o administrador cumprir exatamente os ditames da lei para que sua atividade fosse considerada válida e, para além disso, nos casos em que a lei nada previsse, haveria um campo enorme e praticamente irrestrito para a discricionariedade administrativa.

Todavia, com o surgimento e afirmação da juridicidade administrativa, a função do Administrador não encontra a mesma facilidade da época em que a lei era soberana nos ordenamentos jurídicos. De fato, a mudança paradigmática aqui tratada determina ao realizador da função administrativa que observe não só a lei e suas previsões, mas principalmente a Constituição e seus mandamentos.

E é justamente da mudança de referência normativa para a Administração Pública, de uma forma mais restrita para outra mais ampla, que decorrem os principais questionamentos do presente artigo: ao se deparar com uma lei inconstitucional, como deve proceder aquele que exerce a função administrativa? Pode haver atuação administrativa contra legem mesmo sem prévia declaração de inconstitucionalidade do Poder Judiciário? Apenas o Chefe do Poder Executivo ou qualquer agente administrativo, ao se deparar com lei inconstitucional, poderá deixar de aplicá-la?

Antes de responder a tais perguntas, faz-se necessário apresentar um breve histórico sobre a evolução da doutrina pátria, antes e após a Constituição de 1988, a respeito da possibilidade de o Chefe do Poder Executivo apreciar a constitucionalidade de leis.

Com efeito, a evolução do estudo da matéria guardou forte relação com a legislação pátria a respeito do controle judicial de constitucionalidade. O controle concentrado, no Brasil, surgiu somente com a Emenda Constitucional n. 16/65, tendo como exclusivo legitimado para propositura da ação de inconstitucionalidade (ADIN) o Procurador-Geral da República. ${ }^{31}$ Tal exclusividade de legitimação permaneceu até o advento da Constituição brasileira de 1988, isto é, os Chefes do Executivo dos três níveis de organização político-administrativa do estado brasileiro (o Presidente da República, Governadores dos Estados e do Distrito Federal e os Prefeitos dos Municípios) não possuíam competência processual para buscar a declaração, em controle concentrado, da inconstitucionalidade de determinada lei.

Dessa forma, antes da Constituição de 1988, "a doutrina e a jurisprudência haviam se consolidado no sentido de ser legítimo o Chefe do Executivo deixar de aplicar uma lei que considerasse inconstitucional, bem como expedir determinação àqueles submetidos a seu poder hierárquico para que procedessem da mesma forma." ${ }^{32}$ Naquele contexto, caso ocorresse situação de não aplicação de lei por parte do Executivo sob fundamento de inconstitucionalidade, caberia ao particular eventualmente prejudicado o ônus de procurar o 
Judiciário a fim de que este declarasse a constitucionalidade da lei não aplicada - natural e logicamente, a interpretação definitiva oriunda do órgão judicial deveria ser respeitada pela Administração Pública e pelo particular.

Por outro lado, parte da doutrina titubeou em relação a tal posição após o advento da Constituição de 1988, tendo em vista a eliminação da exclusividade de legitimação do PGR para propositura de ADIN: foi previsto um rol de legitimados, entre os quais o Presidente da República e os Governadores dos Estados e do Distrito Federal. Diante desse novo quadro, "como Ihes foi facultado obter o pronunciamento do Supremo Tribunal Federal, em via principal e abstrata, já não se deveria admitir que pudessem, de ofício, negar cumprimento à lei, sem antes tomar a iniciativa de contestar sua validade, inclusive postulando a concessão de medida cautelar que suspendesse sua eficácia." ${ }^{33}$

Não obstante o vacilo inicial da doutrina a respeito do tema após a extensão de legitimados para propor ADIN, pode-se dizer que o entendimento que se tinha antes da Constituição de 1988, no sentido da possibilidade de o Executivo deixar de aplicar lei que considere inconstitucional, prevaleceu na doutrina majoritária e, também, foi reconhecido jurisprudencialmente. Um primeiro argumento utilizado para que essa posição prevalecesse referiu-se ao fato de os Prefeitos, também chefes de Executivo, não estarem legitimados para propositura da ADIN, isto é, não terem sido incluídos no rol ${ }^{34}$ que quebrou a exclusividade de legitimação do PGR. Por isso, "alguns sustentaram que poderiam os Prefeitos, e somente eles, descumprir a lei flagrantemente inconstitucional, determinando a sua não-aplicação para os subordinados hierárquicos." 35 Todavia, tal entendimento trouxe a "consequência curiosa de que, na prática, passaria o Chefe do Executivo municipal a ter, nessa matéria, mais poder que o Presidente e o Governador." ${ }^{36}$ A doutrina, então, não pôde limitar-se apenas a esse argumento meramente formal, até em razão da falta de lógica apontada (diferenciando indevidamente os Chefes de Executivo em idênticas situações), e o principal fundamento para permitir que o Executivo deixe de aplicar leis inconstitucionais continua o mesmo de antes da CF/88: o da supremacia constitucional, isto é, uma das facetas da juridicidade administrativa.

Na doutrina administrativista sobre o tema, cada autor cita os fundamentos principais que, em sua visão, exigem a atuação da Administração Pública nesse sentido. De seu turno, o professor BINENBOJM conseguiu elencar de modo bastante claro - e, ao alcance dessa pesquisa, de forma mais completa - as justificativas que explicam por que uma lei inconstitucional não deve ser aplicada pelo Poder Executivo:

As razões fundamentais que autorizam (e exigem) tal conduta da Administração são as seguintes:

I. a Administração está vinculada direta e primariamente à Constituição, cabendo-Ihe zelar, ao lado dos demais Poderes, pela sua supremacia;

II. diante de uma lei que se Ihe afigure contrária à Constituição, deve o Chefe da Administração ordenar o não cumprimento daquela como condição para a preservação da superioridade hierárquica da Lei Maior;

III. a possibilidade de propositura de ação direta de inconstitucionalidade pelo Presidente da República e pelos Governadores de Estado não é impeditiva do descumprimento auto-executório, pois ao Supremo Tribunal Federal reserva-se a última palavra, mas não o monopólio da interpretação e aplicação da Constituição; 
SCAPIN, Romano - Do princípio da legalidade ao da juridicidade administrativa: a apreciação de constitucionalidade pela Administração Pública

\begin{abstract}
IV. ademais, ainda que assim não fosse, a circunstância de a legitimação ativa para a propositura de ação direta não se estender aos chefes de outros Poderes, como Prefeitos municipais e Presidentes dos Tribunais de Contas, criaria uma situação de desigualdade injustificável entre as diversas administrações públicas do país;

V. por fim, a disciplina da ação declaratória de constitucionalidade, instituída pela Emenda Constitucional $n^{\circ}$ 03/93, ao aludir ao Poder Executivo (e à Administração Pública em todos os níveis federativos, já sob a redação da Emenda Constitucional $n^{\circ} 45 / 2004$ ) como destinatário da decisão, tornou clara a possibilidade do descumprimento da lei pelos órgãos administrativos, com fundamento na sua inconstitucionalidade, quando inexistente pronunciamento do Supremo Tribunal Federal em sede abstrata. Caso contrário, a alusão constante do 102, $\S 2^{\circ}$, da Constituição seria ociosa e inútil..$^{37}$
\end{abstract}

Além desses argumentos, é pertinente adicionar o interessante silogismo do constitucionalista Barroso como justificativa para o descumprimento de lei inconstitucional pela Administração: "[...] A tese é reforçada por um outro elemento: é que até mesmo o particular pode recusar cumprimento à lei que considere inconstitucional, sujeitando-se a defender sua convicção caso venha a ser demandado. Com mais razão deverá poder fazê-lo o chefe de um Poder." 38

Verifica-se, então, que a possibilidade de apreciação de constitucionalidade de leis pelo Poder Executivo e, como possível consequência, o descumprimento de previsão legal que afronte a Constituição é defendida por renomada doutrina ${ }^{39}$ com excelentes argumentos, sendo natural, portanto, que a jurisprudência também adotasse a mesma linha. De fato, há decisões do STF e STJ que consagram tal possibilidade, conforme se vê nos julgados ementados abaixo transcritos:

AÇÃO DIRETA DE INCONSTITUCIONALIDADE. MEDIDA PROVISORIA. REVOGAÇÃO. PEDIDO DE LIMINAR. - POR SER A MEDIDA PROVISORIA ATO NORMATIVO COM FORÇA DE LEI, NÃO E ADMISSIVEL SEJA RETIRADA DO CONGRESSO NACIONAL A QUE FOI REMETIDA PARA O EFEITO DE SER, OU NÃO, CONVERTIDA EM LEI. - EM NOSSO SISTEMA JURÍDICO, NÃO SE ADMITE DECLARAÇÃO DE INCONSTITUCIONALIDADE DE LEI OU DE ATO NORMATIVO COM FORÇA DE LEI POR LEI OU POR ATO NORMATIVO COM FORÇA DE LEI POSTERIORES. O CONTROLE DE CONSTITUCIONALIDADE DA LEI OU DOS ATOS NORMATIVOS E DA COMPETÊNCIA EXCLUSIVA DO PODER JUDICIARIO. OS PODERES EXECUTIVO E LEGISLATIVO, POR SUA CHEFIA - E ISSO MESMO TEM SIDO QUESTIONADO COM O ALARGAMENTO DA LEGITIMAÇÃO ATIVA NA AÇÃO DIRETA DE INCONSTITUCIONALIDADE -, PODEM TÃO-SÓ DETERMINAR AOS SEUS ÓRGÃOS SUBORDINADOS QUE DEIXEM DE APLICAR ADMINISTRATIVAMENTE AS LEIS OU ATOS COM FORÇA DE LEI QUE CONSIDEREM INCONSTITUCIONAIS. - A MEDIDA PROVISORIA N. 175, POREM, PODE SER INTERPRETADA (INTERPRETAÇÃO CONFORME A CONSTITUIÇÃO) COMO AB-ROGATÓRIA DAS MEDIDAS PROVISORIAS N.S. 153 E 156. SISTEMA DE AB-ROGAÇÃO DAS MEDIDAS PROVISORIAS DO DIREITO BRASILEIRO. - REJEIÇÃO, EM FACE DESSE SISTEMA DE AB-ROGAÇÃO, DA PRELIMINAR DE QUE A PRESENTE AÇÃO DIRETA DE INCONSTITUCIONALIDADE ESTA PREJUDICADA, POIS AS MEDIDAS PROVISORIAS N.S. 153 E 156, NESTE MOMENTO, SÓ ESTAO SUSPENSAS PELA AB-ROGAÇÃO SOB CONDIÇÃO RESOLUTIVA, AB-ROGAÇÃO QUE SÓ SE TORNARA DEFINITIVA SE A MEDIDA PROVISORIA N. 175 VIER A SER CONVERTIDA EM LEI. E ESSA SUSPENSÃO, PORTANTO, NÃO IMPEDE QUE AS MEDIDAS PROVISORIAS SUSPENSAS SE REVIGOREM, NO CASO DE NÃO CONVERSAO DA AB-ROGANTE. - O QUE ESTA PREJUDICADO, NESTE MOMENTO EM QUE A AB-ROGAÇÃO ESTA EM VIGOR, E O PEDIDO DE CONCESSÃO DE LIMINAR, CERTO COMO E QUE ESSA CONCESSÃO SÓ TEM EFICACIA DE SUSPENDER "EX NUNC" A LEI OU ATO NORMATIVO IMPUGNADO. E, EVIDENTEMENTE, NÃO HÁ QUE SE EXAMINAR, NESTE INSTANTE, A SUSPENSÃO DO QUE JA ESTA 
SCAPIN, Romano - Do princípio da legalidade ao da juridicidade administrativa: a apreciação de constitucionalidade pela Administração Pública

SUSPENSO PELA AB-ROGAÇÃO DECORRENTE DE OUTRA MEDIDA PROVISORIA EM VIGOR. PEDIDO DE LIMINAR JULGADO PREJUDICADO “SI ET IN QUANTUM".

(ADI 221 MC, Relator(a): Min. MOREIRA ALVES, Tribunal Pleno, julgado em 29/03/1990, DJ 22-10-1993 PP-22251 EMENT VOL-01722-01 PP-00028)

LEI INCONSTITUCIONAL. PODER EXECUTIVO. NEGATIVA DE EFICÁCIA.

$O$ Poder Executivo deve negar execução a ato normativo que lhe pareça inconstitucional.

(REsp 23121/GO, rel. Min, Humberto Gomes de Barros, $1^{\text {a }}$ Turma, julgado em 06/10/1993, DJ 08/11/1993). (grifou-se).

Em que pesem os precedentes citados, é de se observar que (mais recente) discussão judicial sobre o tema "apreciação de constitucionalidade" pode abalar o consenso jurisprudencial antes transcrito. Com efeito, discute-se, no âmbito do STF, a aplicabilidade de sua Súmula 347 dentro da atual conjuntura constitucional brasileira. Embora a redação dessa Súmula refira-se à atuação dos Tribunais de Contas - "o Tribunal de Contas, no exercício de suas atribuições, pode apreciar a constitucionalidade das leis e dos atos do Poder Público", o fundamento que inspirou seu teor é praticamente o mesmo que autoriza (e exige) a não-executoriedade de leis inconstitucionais

Esclarece-se, de forma mais adequada, o debate judicial noticiado: há um mandado de segurança (MS $n^{\circ} 25.888$ ) tramitando no STF em que se discute a correção de se aplicar a Súmula n. 347 dentro da atual conjuntura constitucional brasileira. O motivo da impetração do MS, em resumo: o Tribunal de Contas da União (TCU) determinou à Petrobrás não aplicar um Decreto, com base em tal Súmula, uma vez que inconstitucional. De seu turno, a Petrobrás impetrou MS, com pedido de medida liminar, alegando que a Súmula $n^{\circ} 347$ do STF foi editada em 1963, tendo como base o art. 77 da Constituição de 1946, já revogado há muito tempo. Diante de tal argumento, o Ministro Gilmar Mendes deferiu a liminar, acolhendo a tese da estatal impetrante, in verbis:

\begin{abstract}
Não me impressiona o teor da Súmula $n^{\circ} 347$ desta Corte, segundo o qual "o Tribunal de Contas, no exercício de suas atribuições, pode apreciar a constitucionalidade das leis e dos atos do Poder Público". A referida regra sumular foi aprovada na Sessão Plenária de 13.12.1963, num contexto constitucional totalmente diferente do atual. Até o advento da Emenda Constitucional $n^{\circ} 16$, de 1965 , que introduziu em nosso sistema o controle abstrato de normas, admitia-se como legítima a recusa, por parte de órgãos não-jurisdicionais, à aplicação da lei considerada inconstitucional. ${ }^{40}$
\end{abstract}

De outro lado, é importante conhecer trecho da fundamentação utilizada no julgamento do leading ase que gerou a edição da Súmula 347 - o Recurso em Mandado de Segurança n 8.372, do Ceará. No julgamento, o Ministro Relator apresentou a seguinte distinção: "Mas há que distinguir entre declaração de inconstitucionalidade e não aplicação de leis inconstitucionais, pois esta é obrigação de qualquer tribunal ou órgão de qualquer dos poderes do Estado."

Todavia, tal distinção estaria totalmente superada, segundo alguns defendem, a partir da Súmula Vinculante $n^{0} 10$ do STF. ${ }^{41}$ A partir da edição dessa Súmula, argumenta-se que não haveria mais dúvidas no sentido de que também "exerce o controle incidental de constitucionalidade o juiz ou tribunal que afasta a aplicação da norma, em face da inconstitucionalidade, mesmo sem a declaração ou reconhecimento expresso na decisão"42, do que decorre que "apreciação de constitucionalidade" e "controle de constitucionalidade" seriam, 
tecnicamente, expressões sinônimas.

No entanto, adota-se, no presente artigo, a posição de que há distinção entre as duas expressões: o controle de constitucionalidade, atribuição exclusiva do Poder Judiciário, opera no plano da validade das normas (leis), de modo que a decisão pela inconstitucionalidade da norma analisada geraria, em regra, sua nulidade desde sua promulgação (decisão com efeitos ex tunc); a apreciação de constitucionalidade, atribuição de todos os órgãos e Instituições que compõem o Estado Democrático de Direito, opera no plano da eficácia das normas (leis), de modo que a conclusão pela inconstitucionalidade de determinada lei geraria somente a suspensão dos efeitos da lei analisada (e apenas a partir da decisão - efeitos ex nunc).

De qualquer modo, não é no aspecto formal da questão que o presente trabalho pretende focar, mas sim no material, ou seja, a discussão mais importante, já travada nos parágrafos acima, é se apenas o Judiciário poderia determinar a inaplicabilidade de uma lei, por considerá-la inconstitucional. Conforme sustentado acima, com a mudança de paradigma da legalidade à juridicidade administrativa, os órgãos dos Poderes Executivo e Legislativo (incluindo-se, pois, os Tribunais de Contas $^{43}$ ) automaticamente analisarão a constitucionalidade das leis que Ihe forem aplicáveis. Mais uma vez, destaca-se que o Estado é de Direito e não apenas o Judiciário é de Direito, razão pela qual os Poderes/órgãos de todo o Estado também estão autorizados a fazer a análise de constitucionalidade em concreto.

Assim, reforça-se o eixo principal do presente artigo: independentemente da expressão que se utilize para denominar a análise da constitucionalidade de leis pela Administração Pública, o fato é que se reconhece tal possibilidade como correta e, mais do que isso, pretende-se apresentar elementos, requisitos e conformações mínimas para as hipóteses de sua realização.

\subsection{APRECIAÇÃO DE CONSTITUCIONALIDADE PELA ADMINISTRAÇÃO PÚBLICA: ASPECTOS DE IMPRESCINDÍVEL OBSERVÂNCIA NOS PROCEDIMENTOS CORRELACIONADOS}

No último capítulo do presente artigo, pretende-se abordar aspectos importantes da atuação da Administração Pública quando da apreciação de constitucionalidade de leis, sem, todavia, ter-se a ousadia de tentar esgotar a matéria, dada a complexidade e riqueza de conteúdo do tema, somada à natureza estreita deste trabalho de pesquisa.

De fato, alguns elementos devem ser obrigatoriamente observados para que a possibilidade aventada na presente pesquisa não torne insustentável o sistema normativo vigente. Logicamente, deixar que qualquer análise de constitucionalidade seja feita de forma desregrada significaria o caminho para a anarquia normativa, em especial nos casos em que tal apreciação ocorrer no âmbito da Administração Pública, situação ainda incipiente no sistema normativo brasileiro. Dessa forma, é preciso definir qual a maneira adequada de fazer a avaliação administrativa de constitucionalidade de leis.

De início, refere-se que a apreciação de constitucionalidade, no âmbito da Administração Pública, pode ocorrer, teoricamente, por qualquer agente administrativo. Isto é, qualquer 
agente público, ao realizar suas atividades relacionadas à função administrativa, pode se deparar com norma inconstitucional, cuja aplicabilidade, por ferir mandamentos de envergadura constitucional, desrespeitaria o Direito vigente. Assim, o núcleo essencial do princípio da juridicidade indicaria a inaplicabilidade, pelo próprio servidor, da norma inconstitucional. Todavia, não se pode olvidar que todas as leis, antes de serem aprovadas, passam por análises prévias de constitucionalidade, o que Ihes confere, por óbvio, uma "presunção de constitucionalidade" que merece ser considerada - e que não pode ser pronta e facilmente afastada diante da conclusão de um único servidor. Aqui, cabe destacar que as análises prévias de constitucionalidade das legislações realizadas no âmbito da União, dos Estados e do Distrito Federal são, por assim dizer, mais confiáveis do que aquelas efetuadas em âmbito municipal, ainda mais quando se trata de municípios pequenos, ${ }^{44}$ tendo em vista a menor qualificação técnico-jurídica, consabida e natural, das Casas Legislativas de tais locais. Não é raro que vereadores, prefeitos e suas respectivas equipes produzam, em conjunto, normas locais inconstitucionais, sem sequer perceber, cujos efeitos podem (e devem) ser evitados o quanto antes.

De qualquer sorte, defende-se que, em regra, a inaplicabilidade de uma legislação tida como inconstitucional por um servidor não pode ocorrer automática e imediatamente, isto é, seus efeitos não podem ser suspensos pela mera e isolada deliberação de um servidor.

Propõe-se, então, que, nos casos de apreciação de inconstitucionalidade, a discussão sobre o dispositivo legal analisado ocorra em processo administrativo aberto específica e exclusivamente para tal fim, por meio do qual sejam cumpridos todos os princípios ${ }^{45}$ cabíveis e pertinentes a justo processo cuja finalidade seja suspender, eventualmente, os efeitos de legislação potencialmente inconstitucional.

No ponto, cabe destacar dois princípios essenciais e indispensáveis para a correta tramitação dos feitos administrativos referidos no parágrafo acima. Com efeito, a suspensão de efeitos de lei cuja inconstitucionalidade é questionada possivelmente atingirá terceiros, que, por tal razão, serão automaticamente interessados no debate jurídico que se travará e, justamente por isso, terão o direito de se manifestar a respeito da matéria. Interessante notar, nesse diapasão, que o contraditório e a ampla defesa são garantidos constitucionalmente aos litigantes em processos judiciais e administrativos. Nesse sentido, cabe transcrever as reflexões do professor Rafael Maffini sobre as consequências de tal garantia constitucional também atingir os processos litigiosos que tramitam na esfera administrativa, in verbis: ${ }^{46}$

\footnotetext{
A Carta Política de 1988 constitucionalizou os princípios do contraditório e da ampla defesa em relação aos processos administrativos (art. $5^{\circ}$, LV, da CF). Nas Constituições anteriores isso não ocorria, ao menos de modo expresso. Após um primeiro momento, em que se comemorou a previsão constitucional de tais garantias em relação aos processos administrativos, doutrina e jurisprudência iniciaram um elogiável itinerário voltado à compreensão do núcleo essencial de tais garantias. Tal núcleo essencial não mais pode se contentar com a simples asseguração formal do contraditório e da ampla defesa, reclamando que haja efetividade no exercício de tais garantias. Neste contexto, por exemplo, situa-se a controvérsia acerca da necessidade da presença de defesa técnica, realizada por advogados, em todos os momentos inerentes a processos administrativos de cunho punitivo. Ainda na tarefa de se encontrar o núcleo essencial da noção referente ao contraditório e à ampla defesa, tem-se afirmado, seja em matéria de poder de polícia, seja em matéria de poder disciplinar, que eventuais restrições impostas pelo Poder Público somente estarão legitimadas sob a perspec-
} 
SCAPIN, Romano - Do princípio da legalidade ao da juridicidade administrativa: a apreciação de constitucionalidade pela

tiva da ampla defesa, caso o seu destinatário tenha tido a oportunidade de uma participação prévia e efetiva no processo que as ensejar. Assim, somente em casos excepcionais, decorrentes de um exercício de ponderação de princípios, se admitiria o diferimento e a postergação do contraditório e da ampla defesa.

Assim, é imperioso que o exercício do contraditório e da ampla defesa seja ofertado, durante a tramitação do respectivo processo administrativo, aos possíveis atingidos pela não-executoriedade de lei cuja constitucionalidade será avaliada.

Outro ponto importante a destacar é a necessidade inexorável de que órgãos/setores estatais jurídicos (como Procuradorias/Assessorias Jurídicas Municipais, Estaduais e Federais) sejam os responsáveis pela abertura e andamento do processo dessa natureza. ${ }^{47}$ Tal necessidade decorre da aplicação simples dos princípios da razoabilidade e da proporcionalidade, uma vez que as carreiras jurídicas são, em razão de sua formação superior específica no curso de Direito (Ciências Jurídicas e Sociais), as mais tecnicamente preparadas para o trato com normas. ${ }^{48}$

É imprescindível, ainda que, a especificação dos procedimentos relacionados a esse tipo de processo (como, por exemplo, a forma pela qual se exercerá o contraditório/ampla defesa, prazos de tramitação, responsabilidade de decisão definitiva, eventual ônus por dolo, etc.) seja devidamente regulamentado de forma positivada, por cada órgão e entidade pública, a fim de se preservar a isonomia e a segurança jurídica.

Impende referir, também, a necessidade de que todos os agentes públicos ajam sob o mesmo Direito e interpretem o Direito da mesma forma. Assim, é indispensável que a Procuradoria/Assessoria Jurídica de maior abrangência na Administração Pública seja a responsável por conduzir referido processo administrativo. Por isso, em se tratando de órgão público que não esteja diretamente subordinado ao Chefe do Executivo (isto, é nos casos de órgãos da Administração Indireta) é prudente a remessa de expediente contendo a lei questionada e os fundamentos que justificariam sua constitucionalidade para a Procuradoria Geral do ente federado a fim de que lá seja iniciado o processo administrativo cabível.

Ainda pensando na isonomia e na segurança jurídica, seria adequado que, ao fim de processo que concluísse pela inconstitucionalidade de determinada lei, fosse expedido decreto (ou outro ato normativo) do Chefe do Poder Executivo direcionado a todos os órgãos/ entidades sob seu controle (utilizando-se, pois, de seu poder hierárquico) para que toda a Administração Pública sob sua chefia passasse a adotar idêntica postura e interpretação em relação à norma cujos efeitos tenham sido suspensos.

Além disso, entende-se que a suspensão dos efeitos de lei inconstitucional não seria o passo final e, por isso, ainda mereceria complementação: o Poder Executivo deveria judicializar a questão imediatamente após a decisão administrativa. Isso visando à análise definitiva da validade da lei, de forma que, em sendo a posição do Judiciário idêntica à do Executivo, a lei será anulada e, consequentemente, expurgada do sistema jurídico vigente..$^{49}$

É importante destacar, também, entendimento pessoal sobre o tema que, se aparentemente audacioso num primeiro momento, mostra-se coerente com o que se espera da atuação da Administração Pública visando à proteção e cumprimento dos principais fins relacionados à essência do Estado Democrático de Direito. Com efeito, entende-se que, 
excepcionalmente, nos casos em que a lei analisada ofenda a Constituição em razão de violação direta a direito fundamental, deverá o próprio agente público suspender a eficácia dos efeitos da lei de forma imediata, cautelarmente, mesmo antes da abertura de processo administrativo específico. Isto é, concede-se a prerrogativa ao agente público de deixar de aplicar legislação que fira diretamente direitos fundamentais dos cidadãos - obviamente, que tal situação implicará a assunção, por parte do agente, dos ônus por uma atuação irresponsável e exigirá a devida fundamentação.

A excepcionalidade ora trazida justifica-se porque os direitos fundamentais possuem papel de destaque no Estado Democrático de Direito e devem ser protegidos incessante e integralmente. Diante da elevada importância dos direitos fundamentais e de seus reflexos para a juridicidade administrativa, o jurista português Paulo Otero ${ }^{50}$ chegou a algumas conclusões interessantes sobre o tema, cabendo destacar duas que, no ponto, são pertinentes:

[...] (3) Perante leis ostensivamente violadoras de tais direitos fundamentais, a Administração Pública encontra-se vinculada a preferir a Constituição à lei, desaplicando as respectivas leis feridas de inconstitucionalidade [...];

(4) A violação administrativa do conteúdo essencial de um direito fundamental acarreta sempre a nulidade dos respectivos atos jurídicos, expressando uma manifestação da especial vinculatividade directa e imediata dos órgãos administrativos às normas de direitos fundamentais.

Assim, conclui-se que, havendo legislação cuja aplicabilidade viole direito fundamental protegido pela Constituição brasileira, ${ }^{51}$ o agente público poderá (e deverá) imediatamente deixar de aplicar a lei, preferindo, pois, o mandamento constitucional, encaminhando expediente para o setor competente, a fim de que se confirme a suspensão cautelar de efeitos e posteriormente se adotem as providências necessárias (e já comentadas), visando a expurgar a norma, em definitivo, do ordenamento jurídico vigente.

\section{CONCLUSÕES}

Em conclusão, assenta-se que a observância a todas as normas jurídico-constitucionais que regulamentam um Estado de Direito é dever de todos os Poderes e Instituições que o integram. No caso da Administração Pública, independentemente da estrutura formal onde as atividades da função administrativa sejam exercidas, não será diferente. De fato, o princípio da juridicidade administrativa, ao substituir o da legalidade, consagrou-se justamente baseado nessa premissa, acrescentando-se que a supremacia do ordenamento jurídico passou a ser da Constituição (e não mais da lei).

Apesar de haver certa dificuldade de se reconhecer que um dos efeitos de tal premissa é a possibilidade de apreciação de constitucionalidade pela Administração Pública, muito provavelmente pelo receio de que tal apreciação ocorra desenfreadamente, a hipótese/consequência apontada é tão lógica quanto uma função matemática.

A apreciação constante e concomitantemente à aplicação das normas infraconstitucionais vigentes é condição necessária para que o Estado Constitucional seja integralmente respeitado. O entendimento de que tal apreciação é prerrogativa exclusiva do Poder Judiciário significa pactuar com a ocorrência de violações a direitos constitucionais, às vezes fundamentais, que devem ser evitados. Em outras palavras: não permitir que a Administração Pública aprecie, mesmo sem análise judicial, se a respectiva legislação está de acordo com 
a Constituição, é sinônimo de autorizar que ofensas a direitos protegidos pelo Estado sejam cometidas pelo próprio Estado.

Portanto, a juridicidade administrativa, reconhecida como princípio norteador da função administrativa em substituição ao da legalidade em sentido estrito, para além de simplesmente autorizar, exige que, em havendo conflito entre disposição legal e constitucional, a Administração Pública prefira a Constituição à lei no momento de aplicar o Direito que embasará suas atividades.

Para tanto, é adequado que um processo administrativo específico formalize tal situação, respeitando-se todos os princípios inerentes aos feitos administrativos, em especial os constitucionais do contraditório e da ampla defesa, a fim de que interesses de terceiro, que seriam justificáveis aprioristicamente pela simples presunção de constitucionalidade das leis, sejam devidamente respeitados.

Nada obstante a utilização de processo específico como procedimento padrão para tais casos, concluiu-se também pela possibilidade de que o próprio agente público deixe de aplicar leis que infrinjam diretamente direitos fundamentais previstos na Constituição, uma vez que a proteção e consecução desses revelam-se como os principais motivos da existência de um Estado Democrático de Direito personificado. Assim, a gravidade da violação legal a dispositivos constitucionais tão caros justificaria a possibilidade de suspensão cautelar dos efeitos da lei inconstitucional, para que, posteriormente mas já com a violação interrompida, o adequado processo administrativo resolva devidamente a questão.

\section{NOTAS}

1. Desde logo, esclarece-se que a presente pesquisa filia-se, quando refere-se a "princípio", aos ensinamentos conceituais do professor Humberto Ávila a respeito do tema, para quem "os princípios descrevem um estado de coisas a ser buscado, sem, no entanto, definir previamente o meio cuja adoção produzirá efeitos que contribuirão para promovê-lo."

2. Os estudos de Direito Romano demonstram que, apesar de o direito consuetudinário ser importante fonte de Direito dos romanos, o Direito escrito também o era, conforme lecionado, exemplificativamente, na obra Direito romano moderno: introdução ao direito civil brasileiro, de José Cretella Júnior.

3. FAGUNDES, Miguel Seabra. O controle dos atos administrativos pelo poder judiciário. 7. ed. Atualizada por BINENBOJM, Gustavo. Rio de Janeiro: Forense, 2005. pp. 115-116.

4. Corrente filosófica, cujos principais expoentes são os pensadores Platão (antiguidade) e Descartes (modernidade), que define o raciocínio como uma operação mental, discursiva e lógica, e o usa como ferramenta para analisar uma ou mais proposições a fim de extrair conclusões de verdade, falsa ou provável sobre elas. Defende que a razão é a única fonte de conhecimento válido.

5. Teoria filosófica que tenta explicar os caminhos que levam as pessoas a formarem Estados e/ou manterem a ordem social e cujos principais pensadores foram: Thomas Hobbes, John Locke e Jean-Jacques Rousseau. Segundo esses filósofos, a noção de contrato traz implícito que as pessoas abrem mão de certos direitos para um governo ou outra autoridade a fim de obter as vantagens da ordem social.

6. RODRIGUES, Itiberê de Oliveira. Fundamentos dogmático-jurídicos da história do princípio da legalidade administrativa no Brasil. In: Fundamentos do Estado de Direito: Estudos em homenagem ao Professor Almiro do Couto e Silva. (Org. Humberto Ávila). São Paulo: Malheiros, 2005 - p. 55. 
SCAPIN, Romano - Do princípio da legalidade ao da juridicidade administrativa: a apreciação de constitucionalidade pela Administração Pública

7. RODRIGUES, Itiberê de Oliveira. Fundamentos dogmático-jurídicos da história do princípio da legalidade administrativa no Brasil. In: Fundamentos do Estado de Direito: Estudos em homenagem ao Professor Almiro do Couto e Silva. (Org. Humberto Ávila). São Paulo: Malheiros, 2005 - p. 56.

8. "Art. 33. A lei disporá sobre a organização administrativa e judiciária dos Territórios."

9. Art. 88. A lei disporá sobre a criação e extinção de Ministérios e órgãos da administração pública.

10. RODRIGUES, Itiberê de Oliveira. Fundamentos dogmático-jurídicos da história do princípio da legalidade administrativa no Brasil. In: Fundamentos do Estado de Direito: Estudos em homenagem ao Professor Almiro do Couto e Silva. (Org. Humberto Ávila). São Paulo: Malheiros, 2005 - p. 56.

11. RODRIGUES, Itiberê de Oliveira. Fundamentos dogmático-jurídicos da história do princípio da legalidade administrativa no Brasil. In Fundamentos do Estado de Direito: Estudos em homenagem ao Professor Almiro do Couto e Silva. (Org. Humberto Ávila). São Paulo: Malheiros, 2005 - p. 56.

12. Um dos motivos para isso, conforme bem adverte o próprio administrativista, é que há situações em que a Administração Pública possui competência normativa autônoma (art. 84, VI, CF/88, com a redação da EC 32/2001), razão pela qual a dependência à prévia lei autorizadora não seria total.

13. MEDAUAR, Odete. Direito Administrativo moderno. 10. edição. São Paulo: Editora Revista dos Tribunais, 2006. p.124.

14. MEIRELLES, Hely Lopes. Direito Administrativo brasileiro. 22. edição. São Paulo: Malheiros, 1997. p. 82.

15. MEDAUAR, Odete. Direito Administrativo moderno. 10. edição, São Paulo: Editora Revista dos Tribunais, 2006. p. 125.

16. Para saber mais sobre a expressão, ver: BARROSO, Luís Roberto. Neoconstitucionalismo e a constitucionalização do direito. Revista de Direito Administrativo, n. 240, 2005, pp. 1-42.

17. BINENBOJM, Gustavo. O sentido da vinculação administrativa à juridicidade no direito brasileiro. In: ARAGÃO, Alexandre Santos de; MARQUES NETO, Floriano de Azevedo, coord. Direito administrativo e seus paradigmas. Belo Horizonte: Fórum, 2008. pp. 149-150.

18. OTERO, Paulo. Legalidade e Administração Pública: o sentido da vinculação administrativa à juridicidade. Coimbra: Livraria Almedina. 2003. p. 733.

19. CANOTILHO, J. J. Gomes. Direito Constitucional e Teoria da Constituição. 6. ed. Coimbra: Almedina, 2002. p. 834.

20. OTERO, Paulo. Legalidade e Administração Pública: o sentido da vinculação administrativa à juridicidade. Coimbra: Livraria Almedina. 2003. p. 735.

21. CANOTILHO, J. J. Gomes. Direito Constitucional e Teoria da Constituição. 6. ed. Coimbra: Almedina, 2002. p. 834.

22. OTERO, Paulo. Legalidade e Administração Pública: o sentido da vinculação administrativa à juridicidade. Coimbra: Livraria Almedina, 2003. p. 735.

23. Destaca-se, por oportuno, que o princípio da supremacia ou primazia da lei também é denominado de princípio da preferência de lei (ou, ainda, precedência ou preeminência de lei).

24. Nesse ponto, cabe esclarecer adequadamente as variações de denominações aos princípios tratados no presente artigo: após o surgimento do princípio da juridicidade administrativa, nos termos acima expostos, parte da doutrina passou a classificar a concepção original do princípio da legalidade como "legalidade em sentido estrito", diferenciando-o da "legalidade em sentido amplo", que correspondia à juridicidade administrativa. 
SCAPIN, Romano - Do princípio da legalidade ao da juridicidade administrativa: a apreciação de constitucionalidade pela Administração Pública

25. Expressão utilizada por Merkl, jurista alemão que, segundo BINENBOJM, foi o maior administrativista kelseniano.

26. Aqui, destaca-se que o presente trabalho reconhece ser o Direito compreendido por todas as normas existentes no ordenamento citado, e apenas por elas, não havendo normas fora desse ordenamento citado que possam compor o Direito vigente.

27. A tradução é livre e o vocábulo grifado não está no original.

28. Grifou-se.

29. Cabe salientar que a catalogação das três alternativas apontadas foi feita pelo professor BINENBOJM, em seu artigo "O sentido da vinculação administrativa à juridicidade no direito brasileiro, p. 160". Quanto à segunda alternativa, destaca-se que o administrativista, ao discorrer sobre o poder regulamentar no direito brasileiro (meio pelo qual a atuação administrativa poderia ser praeter legem), apresentou três correntes doutrinárias divergentes sobre a matéria, a demonstrar que a doutrina não se encontra uníssona nesse ponto. O jurista entende como correta a posição (resumida) de que "será cabível a expedição de regulamentos autônomos em espaços normativos não sujeitos constitucionalmente à reserva de lei (formal ou material), sempre que à míngua do ato legislativo, a Administração Pública estiver compelida a agir para cumprimento de seus deveres constitucionais", fazendo a ressalva de que "também neste caso, por evidente, assegura-se a preeminência da lei superveniente sobre os regulamentos até então editados." BINENBOJM, p. 182.

30. Aqui, destaca-se que a expressão "função administrativa" é tida como sinônimo de "função estatal de Administração Pública". Para definição de "função estatal de Administração Pública", utiliza-se o ensinamento do professor Rafael Maffini no sentido de que: "[...] a função estatal de Administração Pública consiste num instrumento concreto de que o Estado, abstrato que é, se vale para a consecução dos objetivos insculpidos no texto constitucional, sendo encontrada tipicamente no Poder Executivo e, de modo atípico, nas várias outras espécies da estrutura estatal." - MAFFINI, Rafael. Direito Administrativo, 4. ed. rev. atual. e ampl. São Paulo: Editora Revista dos Tribunais, 2013. p. 24.

31. LENZA, Pedro. Direito constitucional esquematizado. 17. ed. São Paulo: Saraiva, 2013. p. 173.

32. BARROSO, Luís Roberto. O controle de constitucionalidade no direito brasileiro: exposição sistemática da doutrina e análise crítica da jurisprudência. 2. ed. São Paulo: Saraiva, 2006. p. 69. Cabe mencionar, por pertinente, que o professor BARROSO acrescenta, ainda, em nota de rodapé na mesma página, que "na verdade, o entendimento deve estender-se aos órgãos dirigentes de quaisquer dos Poderes, na prática de atos materialmente administrativos."

33. BARROSO, Luís Roberto. 0 controle de constitucionalidade no direito brasileiro: exposição sistemática da doutrina e análise crítica da jurisprudência. 2. ed. São Paulo: Saraiva, 2006. p. 70.

34. Referida lista está prevista no art. 103 da Constituição da República, que prevê: Art. 103. Podem propor a ação direta de inconstitucionalidade e a ação declaratória de constitucionalidade: (Redação dada pela Emenda Constitucional $n^{\circ} 45$, de 2004) I - o Presidente da República; II - a Mesa do Senado Federal; III - a Mesa da Câmara dos Deputados; IV - a Mesa de Assembleia Legislativa ou da Câmara Legislativa do Distrito Federal; (Redação dada pela Emenda Constitucional n 45, de 2004) V - o Governador de Estado ou do Distrito Federal; (Redação dada pela Emenda Constitucional n 45, de 2004) VI - o Procurador-Geral da República; VII - o Conselho Federal da Ordem dos Advogados do Brasil; VIII - partido político com representação no Congresso Nacional; IX - confederação sindical ou entidade de classe de âmbito nacional.

35. LENZA, Pedro. Direito constitucional esquematizado. 17 ed. São Paulo: Saraiva, 2013. p. 174.

36. BARROSO, Luís Roberto. 0 controle de constitucionalidade no direito brasileiro: exposição sistemática da doutrina e análise crítica da jurisprudência. 2.ed. São Paulo: Saraiva, 2006. p. 71.

37. BINENBOJM, Gustavo. O sentido da vinculação administrativa à juridicidade no direito brasileiro. In: 
SCAPIN, Romano - Do princípio da legalidade ao da juridicidade administrativa: a apreciação de constitucionalidade pela Administração Pública

ARAGÃO, Alexandre Santos de; MARQUES NETO, Floriano de Azevedo, coord. Direito administrativo e seus paradigmas. Belo Horizonte: Fórum, 2008. p. 188.

38. BARROSO, Luís Roberto. 0 controle de constitucionalidade no direito brasileiro: exposição sistemática da doutrina e análise crítica da jurisprudência. 2. ed. São Paulo: Saraiva, 2006. p. 71.

39. Além dos professores citados no corpo do trabalho, compartilham da mesma tese os seguintes juristas brasileiros: Lucio Bittencourt, Miguel Reale, Themístocles Brandão Cavalcanti, Vicente Ráo, José Frederico Marques, Carlos Maximiliano, Caio Tácito, Ronaldo Poletti, Manoel Gonçalves Ferreira Filho, Alexandre de Moraes e Clèmerson Merlin Clève, conforme lista informada por BINENBOJM, p. 188.

40. Cabe destacar que a decisão do Ministro foi em 22/03/2006 e até hoje não houve o julgamento definitivo do MS, bem como o fato de que o Parecer da Procuradoria-Geral da República, de maio de 2006, foi pela denegação da Segurança.

41. Súmula Vinculante $n^{\circ} 10$ do STF: "VIOLA A CLÁUSULA DE RESERVA DE PLENÁRIO (CF, ARTIGO 97) A DECISÃO DE ÓRGÃO FRACIONÁRIO DE TRIBUNAL QUE, EMBORA NÃO DECLARE EXPRESSAMENTE A INCONSTITUCIONALIDADE DE LEI OU ATO NORMATIVO DO PODER PÚBLICO, AFASTA SUA INCIDÊNCIA, NO TODO OU EM PARTE."

42. ALMEIDA, Vânia Hack de. Controle de constitucionalidade. 2. ed. Porto Alegre: Verbo Jurídico, 2005. p. 53.

43. Cabe ressaltar que a possibilidade de os Tribunais de Contas apreciarem a constitucionalidade das leis locais dos Municípios que fiscaliza e determinar sua negativa de executoriedade não é objeto da presente pesquisa, isto é, o poder de os TCs determinarem a negativa de executoriedade de determinada previsão legal, cuja resposta pela possibilidade ou não dependerá da conclusão acerca da natureza jurídica do órgão de controle externo, não está no escopo pesquisado.

44. Atualmente, são 5.570 municípios existentes no Brasil, todos com competência legislativa própria, sendo que a imensa maioria, possui até $\mathbf{2 0}$ mil habitantes apenas. Segundo dados do IBGE (2000), 1.382 municípios brasileiros possuem até 5.000 habitantes, 1.308, possuem entre 5.001 e 10.000 , e 1.384 , possuem entre 10.001 e $\mathbf{2 0 . 0 0 0 , ~ o ~ q u e ~ t o t a l i z a ~} 4.074$ municípios brasileiros.

45. Sobre os princípios do processo administrativo, cita-se, por todos administrativistas que tratam do tema, a lição de DI PIETRO que, em sua obra Direito Administrativo, elenca (pp. 627-638) tais princípios e discorre sobre cada um.

46. MAFFINI, Rafael. Direito Administrativo, 4. ed. rev. atual. e ampl. São Paulo: Editora Revista dos Tribunais, 2013. p. 126.

47. No ponto, ressalta-se que este, além de vários outros, é importante motivo para que a carreira de Procurador Municipal adquira status constitucional, assim como já ocorre com as carreiras de funções semelhantes nos outros entes federados, a fim de que todos os municípios brasileiros contem, obrigatoriamente, com servidores efetivos de carreira em seus quadros permanentes.

48. Um exemplo de apreciação de constitucionalidade por parte de Procuradoria de ente federado encontra-se no Parecer da PGE-RS n. 15.880/2012.

49. No ponto, cabe explicação, ainda que superficial, sobre o modo pelo qual se retira a lei municipal inconstitucional do mundo jurídico. Como visto, no caso da União, dos Estados da federação e do Distrito Federal, seus Chefes do Executivo são legitimados para propor ADIN, mas, nos casos dos Municípios, não há essa legitimação. Assim, na situação destes, caso a tentativa para solucionar o problema por meio da simples revogação de lei não surta efeito (isto é, caso a Câmara Municipal assim não queira proceder), bem como não seja o caso de buscar a declaração de inconstitucionalidade junto ao respectivo Tribunal de Justiça (situação possível quando a violação constatada fere a Constituição Estadual), o instrumento que poderá ser manejado pelos Municípios é a ADPF (Ação de Descumprimento de Preceito Fundamental). 
50. OTERO, Paulo. Legalidade e administração pública: o sentido da vinculação administrativa à juridicidade. Coimbra: Livraria Almedina, 2011. p. 741.

51. Aqui, esclarece-se que, por direito fundamental, deve-se entender todos aqueles que a Constituição assim expressamente definir, bem como aqueles que o Supremo Tribunal Federal, em decisão definitiva, assim reconhecer.

\section{REFERÊNCIAS}

ARAGÃO, Alexandre Santos de. A concepção pós-positivista do princípio da legalidade. Revista de Direito Constitucional e Internacional. São Paulo, n. 65, out./dez. 2008, p. 7-21.

ÁVILA, Humberto Bergmann. A distinção entre princípios e regras e a redefinição do dever de proporcionalidade. Revista de Direito Administrativo. Rio de Janeiro, n. 215, jan./mar.1999, p. 151-179.

ÁVILA, Humberto Bergmann. Neoconstitucionalismo: entre a ciência do direito e o direito da ciência. Revista Brasileira de Direito Público. Belo Horizonte, n. 23, out./dez. 2008, p. 9-30.

ÁVILA, Humberto Bergmann. Princípios e regras e a segurança jurídica. Revista de Direito do Estado. Rio de Janeiro, v. 1, n. 1, jan/mar 2006, p. 189-206.

ÁVILA, Humberto Bergmann. Teoria dos princípios: da definição à aplicação dos princípios jurídicos. 4.ed. São Paulo: Malheiros, 2005.

BARROSO, Luís Roberto. O controle de constitucionalidade no direito brasileiro: exposição sistemática da doutrina e análise crítica da jurisprudência. 2. ed. São Paulo: Saraiva, 2006.

BINENBOJM, Gustavo. O sentido da vinculação administrativa à juridicidade no direito brasileiro. In: ARAGÃO, Alexandre Santos de; MARQUES NETO, Floriano de Azevedo (Coord.). Direito administrativo e seus paradigmas. Belo Horizonte: Fórum, 2008, p. 145-204.

BINENBOJM, Gustavo. A constitucionalização do direito administrativo no Brasil: um inventário de avanços e retrocessos. Revista Brasileira de Direito Público. Belo Horizonte, n. 14, jul./set. 2006, p. 9-53.

BRASIL. Constituição da República Federativa de 1988. Disponível em: http://www.planalto.gov.br/ ccivil_03/constituicao/constituicaocompilado.htm. Acesso em: 05 out. 2014.

CANOTILHO, J. J. Gomes. Direito Constitucional e Teoria da Constituição. 6. ed. Coimbra: Almedina, 2002.

COUTO E SILVA, Almiro. Princípios da legalidade da administração pública e da segurança jurídica no estado de direito contemporâneo. Revista da Procuradoria-Geral do Estado do Rio Grande do Sul 57. Porto Alegre, 2003, p. 11-31.

CRISTÓVAM, José Sérgio da Silva. A evolução do princípio da legalidade e o controle jurisdicional da discricionariedade administrativa. IDAF: Revista Zênite. Curitiba, n. 25, ago. 2003, p. 14-30.

DI PIETRO, Maria Sylvia Zanella. Direito Administrativo. 26. ed. São Paulo: Atlas, 2013. 
SCAPIN, Romano - Do princípio da legalidade ao da juridicidade administrativa: a apreciação de constitucionalidade pela Administração Pública

princípio da legalidade. Interesse Público. Porto Alegre, n. 79, maio/jun 2013, p. 113-129.

FONTE, Felipe de Melo. Para além da legalidade: a constitucionalização do direito administrativo através do princípio da juridicidade. Algumas propostas. Revista de Direito do Estado. Rio de Janeiro, v. 4, n. 13, jan./mar. 2009, p. 249-267.

GIBSON, Sérgio Armanelli. A ciência jurídica no pós-positivismo: as necessárias repaginações conceituais de segurança jurídica, de regime jurídico-administrativo e do princípio da legalidade administrativa. Fórum Administrativo: Direito Público. Belo Horizonte, n. 93, nov. 2008, p. 60-69.

GRAU, Eros Roberto. Algumas notas para a reconstrução do princípio da legalidade. Revista da Faculdade de Direito da UFMG. Belo Horizonte, v. 29, n. 26/27, 1983/1984, p. 321-329.

GUERRA, Sérgio. Crise e refundação do princípio da legalidade: a supremacia formal e axiológica da Constituição Federal de 1988. Interesse Público. São Paulo, n. 49, mai./jun. 2008, p. 89-111.

LENZA, Pedro. Direito constitucional esquematizado. 17. ed. São Paulo: Saraiva, 2013.

MAFFINI, Rafael. Direito Administrativo, 4. ed. rev. atual. e ampl. São Paulo: Editora Revista dos Tribunais, 2013.

MEIRELLES, Hely Lopes. Direito administrativo brasileiro. 2. ed. São Paulo: Revista dos Tribunais, 1966.

MELLO, Celso Antônio Bandeira de. Curso de Direito Administrativo. 17. ed. rev. e atual. São Paulo: Malheiros, 2004.

MENDES, Gilmar Ferreira. O controle de constitucionalidade das leis no Brasil: evolução e tendências. In: Seminário O Supremo Tribunal Federal na história republicana. Rio de Janeiro, nov. 2001. Anais do seminário. Brasília : AJUFE, 2002, p. 487-567.

MENDES, Gilmar Ferreira. O poder executivo e o poder legislativo no controle de constitucionalidade. Cadernos de Direito Tributário e Finanças Públicas, v. 5, n. 20, jul./set. 1997, p. 11-46.

MOREIRA NETO, Diogo de Figueiredo. Curso de Direito Administrativo. 15. ed. Rio de Janeiro: Forense, 2009.

MOREIRA NETO, Diogo de Figueiredo. Mutações do direito administrativo. 3. ed. Rio de Janeiro: Renovar, 2007.

NÓBREGA, Marcos. O controle do gasto público pelos tribunais de contas e o princípio da legalidade: uma visão crítica. Revista Brasileira de Direito Público. Belo Horizonte, n. 23, out/dez 2008, p. 31-41.

OTERO, Paulo. Legalidade e administração pública: o sentido da vinculação administrativa à juridicidade. Coimbra: Livraria Almedina, 2011.

RODRIGUES, Itiberê de Oliveira. Fundamentos dogmático-jurídicos da história do princípio da legalidade administrativa no Brasil. In: ÁVILA, Humberto (Org.). Fundamentos do Estado de Direito: Estudos em homenagem ao Professor Almiro do Couto e Silva. São Paulo: Malheiros, 2005. 
TÁCITO, Caio. O princípio de legalidade: ponto e contraponto. Revista de Direito Administrativo. Rio de Janeiro, n. 242, out./dez. 2005, p. 125-132.

Recebido em: 01/07/2019

Aceito em: 31/07/2019 